\title{
POŠTA
}

TELEKOMUNIKÁCIE A

ELEKTRONICKY OBCHOD

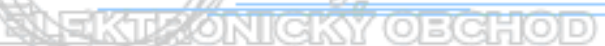

\section{ZLEPŠENIE STRATÉGIE FIRMY NA ZÁKLADE ANALÝZY ZORAĎOVANIA LOKÁLNYCH VÝSLEDKOV V GOOGLE}

\author{
Marek Ďurica*, Lucia Švábová ${ }^{\dagger}$
}

\begin{abstract}
The paper deals with the analysis and quantification of some characteristics of firms that may affect ranking of firms in local search using the search domain Google. Confirmation and quantification of the impact of some qualitative and quantitative characteristics of the firm can be used to formulate recommendations for improving corporate strategy of the firm for acquiring new customers.
\end{abstract}

Keywords: Google search, Electronic commerce, Ranking in Google.

\section{Úvod}

Google je v súčasnosti asi najpoužívanejší internetový vyhl'adávač. Väčšina firiem, ktoré predávajú tovar alebo služby elektronickou formou, sa preto snaží, aby bolo možné ich ponuku prostredníctvom Google vyhl'adat'. Osoba alebo firma, ktorá prostredníctvom Google vyhl'adáva nejaký tovar alebo služby, zadá do vyhl'adávača nejaké kl'účové slovo. Následne si väčšinou vyberá z niekol'kých prvých vyhl'adaných ponúk. Preto je v záujme každej firmy, ktorá predáva vyhl'adávaný produkt, umiestnit' sa na poprednej pozícii v tomto vyhl'adávaní. Ako však tento ciel' dosiahnut'?

V článku sa pokúsime experimentálne zistit', ktoré faktory ovplyvňujú poradie vo vyhl'adávaní v Google. Samozrejme je nutné aj kvantifikovat' vplyv týchto faktorov. Na výber týchto faktorov a na určenie ich vplyvu používame exaktné metódy matematickej štatistiky, konkrétne testovanie hypotéz, korelačnú a regresnú analýzu.

\section{Kódovanie a popis premenných}

$\mathrm{Na}$ základe zadávania kl’účových slov do vyhl’adávača Google sme získali súbor údajov, pri každom vyhl'adávaní boli sledované niektoré charakteristiky, ktoré by mohli, resp. by mali ovplyvňovat' výsledné poradie vo vyhl'adávaní. K jednému kl’účovému slovu sme zaznamenávali prvých 7 výsledkov vyhl'adávania. Týchto vyhl'adávaní bolo spolu 44, to znamená spolu máme 308 meraní. Všetkých 44 vyhl'adávaných kl'účových slov sme za účelom d’alšieho spracovania údajov prerobili na dumy premenné. Každá takáto premenná nadobúda hodnotu 1, ak daný výsledok vyhl'adávania patrí k tomuto kl'účovému slovu,

\footnotetext{
*RNDr. Marek Ďurica, PhD., Katedra kvantitatívnych metód a hospodárskej informatiky, Fakulta prevádzky a ekonomiky dopravy a spojov, Žilinská univerzita v Žiline, Univerzitná 1, 01026 Žilina, tel.: +421415133257

e-mail: marek.durica@fpedas.uniza.sk

† RNDr. Lucia Švábová, PhD., Katedra kvantitatívnych metód a hospodárskej informatiky, Fakulta prevádzky a ekonomiky dopravy a spojov, Žilinská univerzita v Žiline, Univerzitná 1, 01026 Žilina, tel.: +421415133257

e-mail: lucia.svabova@fpedas.uniza.sk
} 
a hodnotu 0 , ak dané meranie $\mathrm{k}$ tomuto kl'účovému slovu nepatrí. Podl'a týchto hodnôt premenných sa dá spätne identifikovat', ku ktorému vyhl'adávaniu daný výsledok patrí.

Pre každé vyhl'adávanie sme získali 7 výsledných meraní, firiem alebo organizácií, ktoré vyhl'adávač Google usporiada podl'a určitého algoritmu do výsledného poradia. Pri každej firme sme sledovali niekol'ko charakteristík, o ktorých sme predpokladali, že by mohli byt' významné pri určovaní výsledného poradia danej firmy vo vyhl'adávaní. Tieto charakteristiky sme rozdelili na kvalitatívne a kvantitatívne. Medzi kvantitatívne charakteristiky daného zariadenia (firmy) sme zaradili:

- Počet citácií - počet citácií v Google s rovnakými údajmi, napríklad meno prevádzky, adresa, telefón, t.j. počet výsledkov vyhl'adávania, ktoré sa zhodujú v niektorom údaji.

- Počet citácií bez čísla - podobný údaj ako predchádzajúca premenná, avšak bez telefónneho čísla.

- Počet +1 - tento údaj sa nachádza v profile firmy, je to podobný údaj ako počet „likes“" na Facebook-u.

- Počet followerov - počet l'udí, ktorí sledujú profil danej firmy, tento údaj sa nachádza $\mathrm{v}$ profile u tých firiem, ktoré majú aktívny Google+ profil.

- Počet hodnotení - počet hodnotení v lokálnom profile, slovné hodnotenia od užívatel'ov.

- Hodnotenie - priemerný počet hviezdičiek v hodnotení firmy.

Tieto kvantitatívne premenné môžu nadobúdat' len celočíselné hodnoty (okrem premennej Hodnotenie), najmenšia možná hodnota je 0 . Ďalej sme sledovali niekol'ko kvalitatívnych premenných, ktoré nadobúdajú slovné hodnoty „áno“ a „nie“. Za účelom d'alšieho spracovania údajov sme tieto hodnoty transformovali na celočíselné hodnoty, pričom áno $=1$ a nie $=0$. Sledované kvalitatívne charakteristiky boli nasledujúce:

- Overená firma - overené firmy majú vedl'a svojho loga ikonu, označenie overenia.

- Klúčové slovo v názve - údaj o tom, či firma má vo svojom názve uvedené kl'účové slovo svojej činnosti.

- Fotky - údaj o tom, či firma má vo svojom profile pridané fotky.

- Relevantný popis - údaj o tom, či firma má v profile pridaný relevantný popis, teda taký, čo aspoň raz obsahuje kl'účové slovo.

- Správna kategória - údaj o tom, či má firma vo svojom profile správne zvolenú kategóriu svojej činnosti.

- Profil prepojenýs $G+$ - prepojené profily umožňujú funkciu sledovania.

- Profil na webe - údaj sa nachádza v sekcii Kontakty, hovorí o tom, či firma má lokálny profil umiestnený na webe, cez Google mapu.

- $G^{+}$prepojený s webom - v profile firmy vedl'a adresy webovej stránky je označenie prepojeného webu.

Týchto 8 dumy premenných bude určovat' kvalitatívne charakteristiky daného zariadenia (firmy). 


\section{Ciele analýzy a metódy spracovania údajov}

$\mathrm{Na}$ základe získaného súboru údajov sme analyzovali vplyv jednotlivých charakteristík na umiestnenie danej firmy v poradí vo vyhl'adávaní v Google. Analýza týchto závislostí a odhalenie vplyvu významných charakteristík môže danej firme pomôct' pri vol'be jej optimálnej stratégie a získavaní nových zákazníkov. Na základe poznania vzt’ahov medzi poradím umiestnenia vo vyhl'adávaní a charakteristikami firmy si môže daná firma zlepšit' svoju pozíciu, čo jej prinesie nových zákazníkov a nové zisky. Ciel’om analýzy bolo odhalit', ktoré zo sledovaných kvalitatívnych alebo kvantitatívnych charakteristík firmy významne ovplyvňujú umiestnenie danej firmy v poradí vo vyhl'adávaní v Google. Tento vplyv danej charakteristiky na výsledné poradie sme sa d’alej nažili kvantifikovat'. Pri analýze získaných údajov boli použité základné štatistické metódy. Premenné sme popísali pomocou ich základných štatistických charakteristík. Ďalej sme ich analyzovali graficky. Skúmali sme vplyv každej dumy premennej na výsledné hodnoty poradia vo vyhl'adávaní, a to pomocou grafickej analýzy, testovania štatistických hypotéz a korelačnej analýzy. Zahrnutím všetkých premenných, kvalitatívnych aj kvantitatívnych a tiež všetkých vyhl'adávaných kl'účových slov, sme hl'adali najlepší lineárny model závislosti poradia od týchto premenných. Pomocou tejto regresnej analýzy sme hl'adali závislosti medzi poradím umiestnenia vo vyhl'adávaní v Google a jednotlivými charakteristikami firmy. Pomocou odhadnutého lineárneho modelu môžeme formulovat' odporúčania pre firmu, ktoré jej pomôžu v zlepšení jej poradia vo vyhl'adávaní, pričom vplyv jednotlivých charakteristík vieme presnejšie špecifikovat'.

\section{Analýza vplyvu kvalitatívnych premenných na umiestnenie v poradí vo vyhl’adávaní}

$\mathrm{Na}$ základe jednoduchého triedenia výsledných poradí podl'a hodnôt kvalitatívnych premenných sme porovnávali priemerné poradie vo vyhl'adávaní. Hodnoty poradia sme analyzovali pre každú kvalitatívnu premennú a skúmali sme, či jej vplyv je na hodnoty poradia štatisticky významný. Pri zvolenej hladine významnosti 0,10 sa ako významne ovplyvňujúce poradie ukázali byt' dve kvalitatívne charakteristiky firmy, a to Profil na webe a Klúčové slovo v názve. Prvá premenná, Profil na webe, hovorí o tom, či daná firma má alebo nemá vytvorený vlastný lokálny profil na webe, cez Google mapu, ktorý si môže potenciálny zákazník pozriet' v sekcii kontaktov. Druhá premenná, Klúúové slovo v názve, hovorí o tom, či má daná firma v názve profilu aj kl'účové slovo, ktoré ju charakterizuje.

\section{Profil na webe}

Použili sme jednoduché triedenie súboru meraní na dve časti podl'a hodnôt premennej Profil na webe. Táto premenná má hodnotu 1 pre tie firmy, ktoré majú lokálny profil umiestnený aj na webe cez Google mapu (107 firiem) a hodnotu 0 pre tie, pri ktorých tomu tak nie je (201 firiem).

V nasledujúcej tabul'ke sú uvedené základné charakteristiky premennej Poradie pre tieto dva súbory údajov. Priemerné poradie firiem, ktoré nemajú profil na webe, je 4,2438 $( \pm 1,9584)$ a pre firmy, ktoré majú profil na webe, je 3,5421 $( \pm 2,0154)$. Rozdiel medzi týmito priemermi je 0,7017 .

\begin{tabular}{|cccc|}
\hline Profil na webe & Mean & Std Dev & N \\
\hline $\mathbf{0}$ & 4,2438 & 1,9584 & 201 \\
\hline 1 & 3,5421 & 2,0154 & 107 \\
\hline
\end{tabular}


V predchádzajúcej tabul'ke je vidiet' aj to, že zo všetkých 308 firiem je 107 označených ako firma, ktorá má profil na webe, a 201 ako firma, ktorá nemá profil na webe. Priemerná hodnota Poradia pre firmy bez profilu je 4,2438 $( \pm 1,9584)$ a pre firmy s profilom je 3,5421 ( $\pm 2,0154)$.

Hodnoty priemerov $\mathrm{v}$ jednotlivých súboroch sa líšia cca o 0,7. Tento rozdiel priemerných hodnôt sme overili pomocou štatistického testovania hypotéz. Použili sme t-test zhody stredných hodnôt dvoch náhodných výberov. Týmto testom exaktne overujeme, či rozdiel medzi priemernými hodnotami poradí 4,2438 a 3,5421 je štatisticky významný, alebo ide len o náhodný rozdiel.

Overíme štatistickú významnost' tohto rozdielu priemerov. Pri použití spomínaného ttestu je potrebné najskôr overit' rovnost' rozptylov dvoch súborov, a to pomocou F-testu. Výsledky testu sú v nasledujúcej tabul'ke.

\begin{tabular}{|l|cccc|}
\hline \multicolumn{5}{|c|}{ Equality of Variances } \\
\hline Variable & Num DF & Den DF & F Value & Pr $>$ F \\
\hline Poradie & 106 & 200 & 1,06 & 0,7221 \\
\hline
\end{tabular}

Podl'a p-hodnoty testu (Pr > F), ktorá je väčšia ako zvolená hladina významnosti 0,10 , rozptyly súborov nepovažujeme za významne rozdielne. Tento test slúžil na rozhodnutie o d'alšom použití testu zhody stredných hodnôt dvoch súborov meraní, roztriedených podl'a hodnoty premenenej Profil na webe. Na základe výsledku tohto testu teda d'alej použijeme ttest zhody stredných hodnôt, ktorý predpokladá rovnaké rozptyly súborov. Výsledky testovania zhody stredných hodnôt sú uvedené v nasledujúcej tabul'ke.

\begin{tabular}{|c|cccc|}
\hline \multicolumn{5}{c}{ T-Test } \\
Variable & Variances & DF & t Value & $\operatorname{Pr}>|\mathbf{t}|$ \\
\hline Poradie & Equal & 306 & 2,96 & 0,0033 \\
\hline
\end{tabular}

Ked’že $\mathrm{p}$-hodnota tohto testu $(\operatorname{Pr}>|\mathrm{t}|)$ je menšia ako zvolená hladina významnosti 0,10 , potvrdila sa rozdielnost' stredných hodnôt týchto dvoch súborov. Teda rozdiel medzi priemerným poradím vo vyhl'adávaní v Google pre firmu s vlastným profilom na webe a priemerným poradím pre firmu bez neho môžeme považovat' za významný, čo sme potvrdili aj štatistickým testom. Teda môžeme tvrdit', že premenná Profil na webe má významný vplyv na výsledné poradia vo vyhl'adávaní v Google. Získaný výsledok potvrdila aj následná grafická analýza. Na nasledujúcom obrázku je vidiet', že na prvých miestach vo vyhl'adávaní sa umiestnili tie firmy, ktoré profil na webe majú (platí hlavne o druhom mieste) a naopak, posledné miesta obsadili firmy, ktoré profil nemajú. Tiež zo 108 overených firiem je až 58 na prvých troch miestach vo vyhl'adávaní, teda viac ako $50 \%$. 


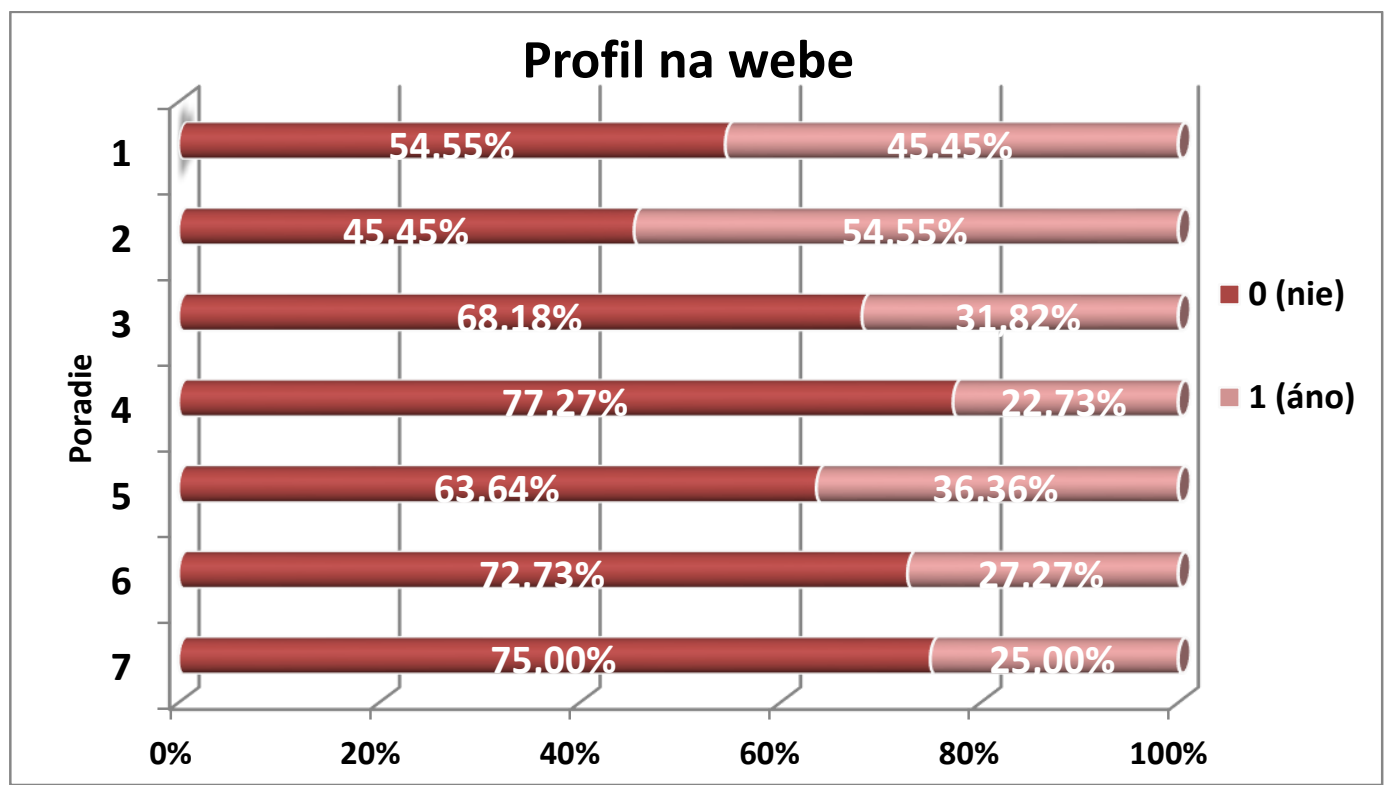

Rozdiel 0,7017 medzi strednými hodnotami premennej Poradie pre firmy s profilom na webe a bez neho znamená, že firmy s profilom dosahujú v priemere o 0,7017 „bodu“ lepšie poradie vo vyhl'adávaní. Za predpokladu, že všetky ostatné premenné ostanú nezmenené a firma si vytvorí vlastný profil na webe, zlepší sa jej poradie vo vyhl'adávaní v priemere o 0,7017 bodu.

Táto hodnota je zároveň aj hodnotou regresného koeficientu pri premennej Profil na webe v jednoduchej lineárnej regresii, ktorá modeluje lineárnu závislost' Poradia od jedinej premennej Profil na webe.

\section{Kl’účové slovo v názve}

Ďalšou premennou, podl'a ktorej rozdelíme súbor na dve časti je premenná Klúčové slovo $v$ názve. Táto premenná má hodnotu 1 pre tie firmy, ktoré majú vo svojom profile v názve aj príslušné kl'účové slovo (170 firiem) a hodnotu 0 pre tie firmy, ktoré vo svojom profile príslušné kl'účové slovo nemajú (138 firiem).

V korelačnej analýze sa korelácia tejto premennej s premennou Poradie ukázala byt' štatisticky významná, čo znamená, že medzi týmito dvoma premennými existuje lineárna závislost'. Ako sa dá predpokladat', hodnota korelačného koeficienta medzi premennou Poradie premennou Klúčové slovo vnázve je záporná, teda zmena hodnoty premennej Klúčové slovo v názve $\mathrm{z}$ hodnoty 0 na hodnotu 1 spôsobí pokles $\mathrm{v}$ hodnote premennej Poradie, teda zlepší sa poradie firmy vo vyhl'adávaní.

V nasledujúcej tabul'ke sú uvedené základné charakteristiky premennej Poradie pre tieto dva súbory údajov. Priemerné poradie firiem, ktoré nemajú klúúcové slovo v názve, je 4,2391 $( \pm 1,9763)$ a pre firmy, ktoré majú kl’účové slovo v názve, je 3,8059 $( \pm 2,0097)$. Rozdiel medzi týmito priemermi je 0,4332 .

\begin{tabular}{|cccc|}
\hline Klúčové slovo v názve & Mean & Std Dev & N \\
\hline $\mathbf{0}$ & 4,2391 & 1,9763 & 138 \\
\hline 1 & 3,8059 & 2,0097 & 170 \\
\hline
\end{tabular}

Rovnako, ako pri predchádzajúcej premennej, overíme štatistickú významnost' tohto rozdielu priemerov. Najskôr však musíme otestovat' rovnost' rozptylov týchto súborov a to pomocou F-testu. Výsledky testu sú v nasledujúcej tabul'ke. 


\begin{tabular}{|c|cccc|}
\hline \multicolumn{5}{|c|}{ Equality of Variances } \\
\hline Variable & Num DF & Den DF & F Value & Pr $>$ F \\
\hline Poradie & 169 & 137 & 1,03 & 0,8415 \\
\hline
\end{tabular}

Podl'a p-hodnoty testu $(\operatorname{Pr}>\mathrm{F})$, ktorá je väčšia ako zvolená hladina významnosti 0,10 , rozptyly súborov nepovažujeme za významne rozdielne. Preto d'alej použijeme t-test zhody stredných hodnôt, ktorý predpokladá rovnaké rozptyly súborov.

\begin{tabular}{ccccc}
\hline Variable & Variances & DF & t Value & $\operatorname{Pr}>|\mathbf{t}|$ \\
\hline Poradie & Equal & 306 & 1,9 & 0,0590
\end{tabular}

Ked’že p-hodnota tohto testu $(\operatorname{Pr}>|t|)$ je menšia ako zvolená hladina významnosti 0,10 , potvrdila sa rozdielnost' stredných hodnôt týchto dvoch súborov. Teda rozdiel medzi priemerným poradím vo vyhl'adávaní v Google pre firmu s klúčovým slovom v názve a priemerným poradím pre firmu bez neho môžeme považovat' za významný, čo sme potvrdili aj štatistickým testom. Teda môžeme tvrdit', že premenná Klúčové slovo v názve má významný vplyv na výsledné poradia vo vyhl'adávaní v Google.

Rovnako ako u predchádzajúcej premennej, tento výsledok sme potvrdili aj následnou grafickou analýzou.

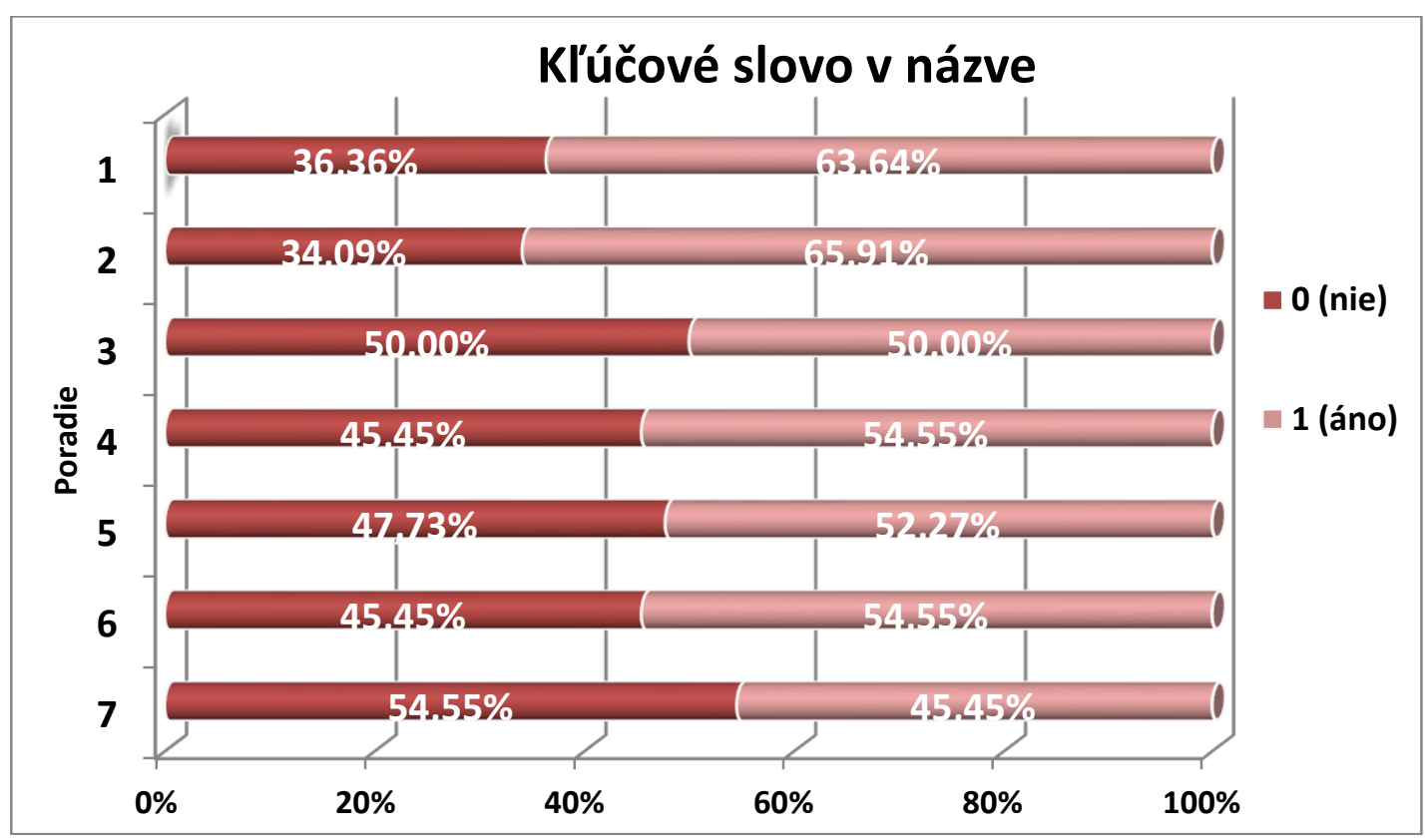

Ako je vidiet' na predchádzajúcom obrázku, Kl'účové slovo v názve má na umiestnenie vo vyhl'adávaní taký vplyv, že prvé miesta obsadzujú práve tie firmy, ktoré kl’účové slovo vo svojom názve majú. Na poslednom mieste sa umiestňujú prevažne tie firmy, ktoré kl'účové slovo v názve nemajú.

Rozdiel 0,4332 medzi strednými hodnotami premennej Poradie pre firmy s kl'účovým slovom v názve a bez neho znamená, že firmy, ktoré majú klúčové slovo v názve, dosahujú v priemere o 0,4332 ,bodu“ lepšie poradie vo vyhl'adávaní. Za predpokladu, že všetky ostatné premenné ostanú nezmenené a firma si do svojho názvu profilu zaradí aj príslušné kl'účové slovo, ktoré ju charakterizuje, zlepší sa jej poradie vo vyhl'adávaní v priemere o 0,4332 bodu. 
Táto hodnota je zároveň aj hodnotou regresného koeficientu pri premennej Klúúové slovo v názve v jednoduchej lineárnej regresii, ktorá modeluje lineárnu závislost' Poradia od jedinej premennej Klúčové slovo v názve.

\section{Regresná analýza}

Pomocou regresnej analýzy sme modelovali hodnoty premennej Poradie v závislosti od hodnôt ostatných vysvetl'ujúcich premenných. Poradie sme modelovali lineárnym regresným modelom. Tento model sme vytvárali rôznymi spôsobmi:

- Do modelu sme zaradili všetky nezávislé premenné a na základe testu významnosti ich regresného koeficientu sme postupne odstraňovali tie premenné, ktoré boli v modeli nevýznamné. Tento prístup sa nazýva Backward elimination. Týmto postupom sme na záver dostali lineárny regresný model len s troma vysvetl'ujúcimi premennými. Ostatné premenné sme postupne odstraňovali tak, aby p-hodnota testu významnosti ich regresného koeficientu bola aspoň na hladine 0,10 . Výsledný model je uvedený nižšie.

- Do modelu sme postupne pridávali premenné na základe p-hodnoty testu významnosti ich regresného koeficientu. Tento prístup sa nazýva Forward selection. Týmto postupom sme dostali rovnaký výsledný model, ako v predchádzajúcej metóde.

- Metódou Maximum R-squared improvement sme do modelu zarad'ovali tie premenné, pri ktorých bola hodnota koeficientu determinácie maximálna. Takto sme vytvárali postupne model s jednou vysvetl'ujúcou premennou, dvoma, troma, atd'. Potom sme vybrali najvhodnejší z týchto modelov na základe testov významnosti regresných koeficientov vo vytvorených modeloch. Ako najvhodnejší získaný model sa ukázal byt' model s troma vysvetl'ujúcimi premennými, rovnaký ako v predchádzajúcich dvoch metódach.

- Do modelu sme zaradili tie premenné, ktorých korelácia s premennou Poradie bola štatisticky významná na hladine významnosti 0,10 . Zároveň sme brali do úvahy možné závislosti medzi vysvetl'ujúcimi premennými. Výsledný regresný model sme potom vytvorili metódou postupného vyrad’ovania premenných na základe štatistickej významnosti ich regresných koeficientov.

Ako bolo spomenuté, všetkými štyrmi spôsobmi sme dostali rovnaký výsledný lineárny regresný model, ktorý je uvedený v nasledujúcej tabul'ke.

\begin{tabular}{|cccccc|}
\hline Variable & Estimate & Error & Type II SS & F Value & Pr $>$ F \\
\hline Intercept & 4,53483 & 0,18767 & 2249,071 & 583,92 & $<, 0001$ \\
\hline Počet citácii & $-0,00137$ & 0,0007164 & 14,11622 & 3,66 & 0,0565 \\
\hline $\begin{array}{c}\text { Klúčcové slovo } \\
\text { v názve }\end{array}$ & $-0,38333$ & 0,22539 & 11,14109 & 2,89 & 0,0900 \\
\hline Profil na webe & $-0,71203$ & 0,23549 & 35,21323 & 9,14 & 0,0027 \\
\hline
\end{tabular}

V druhom stĺpci tabul'ky sú uvedené odhadnuté hodnoty regresných koeficientov (Parameter Estimate). V poslednom stĺpci tabul'ky sú p-hodnoty testu ich významnosti, ktoré sú všetky menšie ako hladina 0,10 .

Uvedieme ešte test významnosti modelu ako celku pomocou analýzy rozptylu. Tento test overuje vhodnost' použitia lineárnej regresie na analyzované údaje. Na základe p-hodnoty 
testu môžeme povedat', že lineárny regresný model bol vhodne zvolený a model ako celok je štatisticky významný na hladine významnosti 0,10 .

\begin{tabular}{|c|rrrrr}
\hline \multicolumn{5}{c}{ Analysis of Variance } \\
Source & \multicolumn{1}{c}{ DF } & Sum of Squares & Mean Square & F Value & Pr > F \\
\hline Model & 3 & 61,08575 & 20,36192 & 5,29 & 0,0014 \\
\hline Error & 304 & 1170,9143 & 3,85169 & & \\
\hline Corrected Total & 307 & 1232 & & & \\
\hline
\end{tabular}

Podl'a p-hodnoty je vidiet', že lineárna regresia bola na modelovanie vzt'ahu medzi týmito premennými vhodne zvolená a model ako celok je štatisticky významný. rovnicou:

Tento regresný model teda popisuje hodnoty premennej Poradie nasledujúcou

Poradie $=4,53483-0,00137$. Počet citácií $-0,38333$. Klúčové slovo v názve 0,71203. Profil na webe

Aj na základe regresných koeficientov v predchádzajúcom modeli je vidiet', že okrem konštanty najvýznamnejší vplyv na hodnotu Poradia má premenná Profil na webe, ktorej regresný koeficient je v absolútnej hodnote najväčší a aj podl'a $\mathrm{p}$-hodnoty $\mathrm{v}$ poslednom stípci je najvýznamnejší.

\section{Záver}

Ciel’om analýzy bola identifikácia a kvantifikácia faktorov ovplyvňujúcich poradie vo vyhl'adávaní v Google. Preto sme urobili 44 vyhl'adávaní pre rôzne kl'účové výrazy. Pri každom vyhl'adávaní sme brali do úvahy prvých 7 výsledkov vyhl'adávania. Pri týchto vyhl'adaných ponukách sme sledovali 14 rôznych faktorov, ktoré sme si vytipovali ako tie, ktoré by podl'a nás mohli ovplyvňovat' poradie vo vyhl'adávaní. Z týchto faktorov je 6 kvantitatívnych a zvyšných 8 kvalitatívnych.

Z kvalitatívnych faktorov sa ukázali byt' významné dve. Prvým je to, či má firma vytvorený vlastný lokálny profil na webe, cez Google mapu, ktorý si môže potenciálny zákazník pozriet' v sekcii kontaktov. Ukazuje sa, že firmy s profilom dosahujú v priemere o 0,7017 „bodu“ lepšie poradie vo vyhl'adávaní než firmy bez neho. Druhým faktorom je to, či má daná firma v názve profilu aj vyhl'adávané kl’účové slovo. Firmy, ktoré majú vyhl'adávané kl'účové slovo vo svojom názve, dosahujú v priemere o 0,4332 „bodu“ lepšie poradie vo vyhl'adávaní.

Z regresných analýz vyplýva, že jediným kvantitatívnym faktorom ovplyvňujúcim poradie vo vyhl'adávaní je počet citácií firmy vo vyhl'adávači Google, teda počet výsledkov vyhl'adávania s rovnakými údajmi o firme, ako je názov firmy, telefónne číslo, adresa. Tiež sa potvrdil vplyv spomínaných kvalitatívnych faktorov. Poradie vo vyhl'adavaní sme teda modelovali pomocou regresného modelu s týmito tromi faktormi.

Ak si firma chce zlepšit' poradie vo vyhladavani v Google, tak by si mala zriadit' vlastný lokálny profil na webe, cez Google mapu, dalej by si mala dat do svojho názvu to, čo ponúka a samozrejme by mala mat' čo najvacsí počet citácií v Google. 


\section{Literatúra}

[1] ANDĚL, J.: Základy matematické statistiky, MatfyzPress, Praha, ČR, 2011, 358 str., ISBN 978-80-7378-162-0

[2] STANKOVIČOVÁ, I., VOJTKOVÁ, M.: Viacrozmerné štatistické metódy s aplikáciami, Iura Edition, Bratislava, 2007, 261 str., ISBN 978-80-8078-152-1

[3] ŠOLTÉS, E.: Regresná a korelačná analýza s aplikáciami, Iura Edition, Bratislava, 2008, 287 str., ISBN 978-80-8078-163-7

\section{Grantová podpora}

Tento príspevok bol vytvorený v spolupráci s konzultačnou agentúrou pre internetový marketing Pizza Seo, s.r.o. a je súčast’ou výskumu tejto agentúry v danej oblasti. 